\title{
The Scripture on Tiles: \\ Dutch Tiles as an Example of the Biblical Culture of Everyday in the Republic
}

\author{
PIOTR OCZKO \\ Jagiellonian University \\ Wydział Polonistyki \\ Uniwersytet Jagielloński \\ ul. Gołębia 16 \\ 31-007 Kraków, Poland \\ piotrek.oczko@uj.edu.pl
}

\begin{abstract}
The history of Dutch tiles started in the sixteenth century Antwerp in the workshops of the Italian potters who had settled in the city upon the Scheldt. Due to the political and social factors (i.e. huge wave of refugees during the Dutch Revolt), tile production was moved to the Northern Netherlands, where it was fully developed and the offer of the Republic's tile works began to enjoy greatest fame and a huge commercial success all over Europe. The given article deals mostly with Dutch tiles representing the biblical scenes (bijbeltegels) and discusses their numerous contexts, such as confessional and social background, iconographical origin of their designs (engravings, illustrated Bibles, stencils), the taste and status of the potential buyers. Moreover, the artistic and cultural phenomenon of Dutch biblical tiles has been interpreted in terms of a much wider tradition, namely the 'biblicisation' of everyday life in the Dutch Republic and its interiors. Finally, the issue of Dutch tiles, being the symbols of the national cultural tradition, has been brought up.
\end{abstract}

Keywords: Dutch tiles; Dutch pottery; Bible culture in the Dutch Republic; illustrated Bibles; Dutch interiors 
From the seventeenth till the nineteenth century Dutch tiles enjoyed a great fame all over Europe. Millions of them used to be imported from the Netherlands as the decoration for the walls of the aristocratic palaces, rich houses, and even churches. Tiles also served as the 'emissaries' of Dutch culture as they popularised the image of the country even more successfully than writings, e.g. travel reports. However, their actual history starts in the Southern Netherlands, namely in Antwerp, where in the beginning of the sixteenth century the Italian potters specialising in the art of maiolica settled. First earthenware tiles made by them were multicoloured, mostly ornamental, only accidentally figurative in decoration and primarily designed for the floors, not walls. The most famous existing examples are found in The Vyne Palace in Hampshire (1520) and in the abbey of Herkenrode near Hasselt (1532, fig. 1). Moreover, early Antwerpian tiles not only showed a strong Italian influence, but also some Islamic-inspired, Spanish character (Gruber et al. 1994: 30ff, Kamermans 2013: 20-21, De Jonge 1971: 1-3, 16-27).

The outbreak of the Dutch Revolt resulted in a huge wave of Protestant refugees seeking safer and better life in the Northern Provinces - in case of Antwerp the exodus reached almost half of the city's population. The descendants of the Italian craftsmen, who by that time had already adapted the new faith and language, and their followers headed to London, Norwich, and Hamburg, but above all, to the territories which were soon to become the Dutch Republic. The workshops were established in Middelburg, Haarlem, Amsterdam, Rotterdam, Dordrecht, Utrecht, Hoorn, Gouda and Harlingen; other Frisian towns like Makkum and Bolsward followed a bit later.

From the seventeenth to the twentieth century there were almost 200 workshops producing tiles (tegelbakkerijen) in the Netherlands (Pluis 2013: 89-97). The town of Delft quickly reached the status of a proverbial, leading manufacturing centre of Dutch pottery, though its production focused mostly on plates, dishes, jugs, vases, and decorative objects, tiles being just a tiny fraction of the output. However, the fame and role of Delft resulted in creating a generally used, though incorrect, term Delft tiles, in this case denoting the style but definitely not serving as the actual attribution (the same concerns applying the terms such as Delft blue and delftware to tin-glazed earthenware with blue design, regardless of its place of production).

In the beginning of the seventeenth century, owing to the historical and social factors, the early polychrome earthenware tiles were mostly replaced by the white-and-blue colour scheme. In 1602 and 1604 the ships of the Dutch East India Company (VOC) captured two Portuguese ships carrying a huge amount (a couple of hundred thousands) of Chinese white-and-blue porcelain which was sold on the auctions in Middelburg and Amsterdam in 1607. The sales resulted in a tremendous growth of interest, collecting desires, and insatiable demand for 
blue-painted pottery in the Republic. Consequently, Dutch craftsmen started to imitate in faience the desired porcelain shapes, patterns, and motifs. By analogy, the predominant colour of the tiles was changed for blue, though purple (paars) manganese paints also became popular in the end of the seventeenth century.

Since ca. 1630 onwards, the workshops started to produce the whole series of tiles, amounting to even a couple of dozens of thematically related iconographical patterns. The variety was huge and included landscapes (fig. 2), pastoral scenes (fig. 3) plants (often heaped as still-lives) and animals (both local and exotic, fig. 4), flower vases, playing children (fig.5), cupids (fig. 6), mythological figures and sea creatures (fig. 7), ships (fig. 8), pictorial representations of the proverbs ("Als de vos de passie preekt, boer pas op je kippen" - when a fox preaches on the Passion, a peasant should keep his eye on the chickens, fig. 9), soldiers and riders, genre scenes, sometimes even representations disregarding the issues of decorum and decency (Dutchmen defecating, urinating, and vomiting, Dutchwomen lifting their skirts up to the unspeakable delight of the viewers, fig. 10), and, above all, scenes from the Bible (bijbeltegels), commonly called histories (stories, fig. 11, 12, 35). These biblical tiles provide us with an invaluable insight into the common way of understanding and perceiving of the sacrum in the past, at the same time being the most precious documents in the field of not only the iconography, but also confessional culture.

In the course of ca. 250 years 592 scenes from both Old (319) and New Testament (273) served as the inspiration for tiles; documented by more than 10.000 various objects that have been registered so far (Pluis 1994). Naturally, tile artists preferred the biblical verses with an evident narrative potential, such as the stories from the Books of Genesis, Exodus, Judges, Samuel, Kings, four Gospels, Acts of the Apostles, and the Book of Revelation. Contrary, the Books of Leviticus, Deuteronomy, Ezra, Proverbs, Lamentations, Isaiah, Ezekiel, Hosea, Amos, the Psalms, and the Song of Songs enjoyed much less - or even none - popularity, due to their strictly discursive, prescriptive, non-narrative and non-illustrative character. Certain motifs appeared more frequently than others - Adam and Eve in Paradise, Abraham's sacrifice of Isaac, the baptism of Jesus, the crucifixion etc. being used quite often, the stories of Nadab and Ahibu or the prophet Agabus from the Acts of the Apostles being painted only once in a blue moon (Pluis 1969: 8). Generally speaking, the scenes from the Old Testament outnumbered the stories from the Gospels which was grounded not only in the vaster size of the 'Israelite' section of the Bible, but, as I will further suggest, also in the Dutch cultural factors.

Up to the end of the eighteenth century tile production was mostly reflecting the Protestant confessional aesthetics - the representations that we could probably classify as strictly 'Catholic-oriented' were quite rare (fig. 23). However, since 1853, when the Roman Catholic Episcopal hierarchy was officially restored in the 
Netherlands and the Catholic life started to flourish with many churches being built, tile producers noticed the emerging new market and introduced suitable motifs (fig. 14, 15) (Sprangers 2013: 95-101). Surprisingly, confessional restrictions in tile design were not imposed on the deuterocanonical books (i.e. those not present in the Hebrew Bible and hence regarded by the Protestants as the apocrypha - e.g. the books of Tobit, Judith or Daniel) which were used as a constant source of inspiration. The explanation probably lies in the fact that they were included in the Statenvertaling, but at the back and provided with a warning to the readers. Though the tile makers undoubtedly had the Statenvertaling in mind while working, one interesting exception is known. Ca. 1650 a craftsman from Amsterdam painted thirsty Samson drinking water which sprang out from the ass's jaw (The Book of Judges 15:17-19, fig. 24). It proves that he was familiar with the early Netherlandish rendering of the Vulgate in which God does not open up for Samson a hollow place in Lechei ("de holle plaetse die in Lechei is" - the States translation from 1637) but "een baktand in het ezels kaeksbeen" (a molar in the ass's jaw) from which the water comes out (in Latin: "aperuit itaque Dominus molarem dentem in maxilla asini") (Pluis 1994: 610-611).

Prior to the seventeenth century, Netherlandish tiles with biblical motifs were few and far between. The Scripture was represented mostly in so called tegeltableaus, namely, the tile pictures covering from (at least) two to many dozens of separate tiles, which, when put together, constituted the whole scene. The earliest example known, showing the conversion of Saul (1547), is displayed in the Vleeshuis in Antwerp (fig. 13). The series of separate biblical tiles became more common only in the second half of the seventeenth century and their production reached its peak ca. 1700-1900. Moreover, in the nineteenth century the workshops from Utrecht and Friesland not only brought back and popularised the multi-tile biblical tegeltableaus (fig. 14, 15) on a greater scale, but they also started to cater for the catholic believers, offering them the representations of Virgin Mary or saint Veronica wiping Christ's forehead with her veil.

Dutch tiles were painted with help of the pricked paper sheets - stencils (sponsen). The stencils were put onto the first-fired tile (biscuit) covered with a layer of glaze containing tin oxide. Then, the powdered charcoal was scattered from the bag on the stencil until a basic, dot to dot outline appeared on the tile lying underneath. This 'sketch' was to be now worked upon (i.e. individually hand-painted and enriched by adding various elements like corner motifs - hoekmotieven, ground, grass, bushes, clouds etc). Every single tile prepared by the same artist was slightly different; not to mention the fact that the same pricked stencil was used ca. 100-200 times and the worn ones were replaced with the fresh copies. Throughout the centuries similar patterns were used by many craftsmen from various workshops, resulting in considerable, both individual and local, stylistic differences. 
In turn, stencils were generally based on the engravings from the illustrated Bibles (prentenbijbels, beeldbijbels) (Poortman 1983-1986), sometimes containing prints of the eminent artists such as Albrecht Dürer, Hans Holbein, Peter Paul Rubens or Jan Luiken. The greatest influence, however, had the prints by Mattheüs Merian whose Icones Biblicae (1625-1627) were constantly copied and reworked by the Dutch engravers and republished in many versions, for example in Icones Biblicae by Cornelis Danckerts (1648), Historiae Sacrae Veteris et Novi Testamenti... by Nicolaes Visscher (1650) or Toneel ofte Vertooch der Bybelsche Historien by Pieter Schut (1659) (Pluis 1994: 61-77). Generally speaking, in the eighteenth century biblical tiles from Utrecht (since 1750 on) were based on the prints from Historiae Sacrae..., tiles from Amsterdam on the engravings by Pieter Schut, and the tiles from Rotterdam (being the biggest centre of such production) followed its own local, graphically ungrounded patterns. Because painters used to change their working places and take stencils to other towns, patterns typical for Utrecht could suddenly appear in Friesland and the representations from Rotterdam were reproduced in Amsterdam. In the nineteenth century some new inspirations appeared. For example, the workshops from Utrecht started using the English prints of Richard Westall (Illustrations of the Bible, London, ca.1835) and the catholic Andachtsbilder (devotional images) as tile models.

The process of the iconographical evolution can be exemplified step by step by the following images illustrating the Adoration of the Magi described in the Gospel of Matthew (2:11): 1. copper plate by Mattheüs Merian (fig. 16), 2. Merian's print from Icones Biblicae (fig. 17); 3. Merian-based Dutch engraving from Historiae Sacrae (fig. 18); 4. matching pricked stencil (fig. 19); 5, 6. two tiles made in Utrecht: purple (ca. 1760-1770, fig. 20) and blue (ca. 1790, fig. 21).

Biblical tiles were the most expensive wares in the offers of tegelbakkerijen, costing on average four times more than the tiles depicting pastoral scenes or landscapes. They were usually made by a so called 'first painter' (eerste schilder) in a workshop, the most talented and comprehensive one. Painting biblical scenes, quite complex from the iconographical point of view, required a great artistic skill in reproducing at the same time human figures, buildings, animals, plants, and landscapes; moreover, in some cases, providing also tiny inscriptions referring to the chapters and verses of the Scripture.

These were so called Histories met tekst - biblical stories with captions (fig. 21, 35 ) which entered the production ca. 1720. Under a pictorial representation the textual reference to the appropriate biblical chapter and verse was added (e.g. "GEN 33.V.4") which helped the viewer to attribute the painted scene rightly and immediately. Due to the unprofessional biblical training of the tile painters, mistakes were unavoidable. These were not only natural 'scribal errors' (like transpositions of the numbers in verse reference) but also more conspicuous 
oversights. The Book of the Judges (Latin: Judicum) was mistaken for the apocryphal Book of Judith; Jan Eelkes from Harlingen even 'invented' a "Book of Suzanna" (fig. 22) . Actually, he must have meant the story from the Book of Daniel, but as it was not the part of the Protestant biblical canon and Suzanna played a leading role in the narration, his confusion can be somehow understandable. Moreover, similar iconographic representations from the worn or unsubscribed stencils could be wrongly attributed, Judith with a head of Holofernes becoming Salome with the head of John the Baptist, fortifying of Jerusalem mentioned in the Book of Nehemiah being interpreted as the construction of the Tower of Babel (Pluis 1969: 14-16, Pluis 1994: 40-41).

From the seventeenth century onwards, all over Europe Dutch tiles were mostly used with a strictly representative purpose in mind. They decorated aristocratic palaces and churches covering the walls or even the whole interiors, including the ceilings (e.g. The Menshikov palace in St. Petersburg, fig. 25). However, it must be emphasised that this trend had nothing to do with the fascination with the Dutch bourgeois culture. Just on the contrary, blue painted tiles were simply commonly associated with the fashionable Chinese and Chinese-esque objects (chinoiserie) - as such they had been already applied in the Trianon de Porcelaine built in Versailles in 1670-1674 (Przywoźna-Leśniak 2012: 156). In the Republic the usage of tiles was purely practical. First, their single row covered only the wall on the floor level to avoid making it dirty during constant sweeping (Oczko 2013: 422), as seen in numerous genre paintings (e.g. Vermeer's Milkmaid, Van Hoogstraten's View of a Corridor). Later on, tiles were also put in bigger amounts in the kitchens, chimney places, warehouses or even cellars; finally they found their way to the walls of the rural farmhouses of the Low Countries (boerderijen), in the South (fig. 26) and North (fig. 27) alike.

Biblical tiles, however, were the exception from this rule. Due to their high price, they used to be purchased by the richer customers who aimed at emphasising the higher social status of their interiors, and as such were displayed in more visible spaces like the smuigers - high, representative chimney places (fig. $28,30)$, especially popular in the area of Zaanstreek. Biblical tiles were often purchased by the pious Mennonites inhabiting Zaanstreek, not to mention other religious people eager to confirm their belief. Educational aspect of such tiles was unquestionable - enough to say that the religious zest of Philip Doddridge (1702-1751), the leader of the English Nonconformists and hymnwriter, supposedly started when he, as a kid, was admiring the bijbeltegels decorating his mother's chimney-place (fig. 29).

Moreover, Dutch tiles should be looked upon and interpreted in a wider historical and cultural context, namely the vast reception of the Bible in the Republic. This included a couple of factors, the first one being the Sola Scriptura 
Protestant doctrine forming grounds for everyday reading and studying of the Word of God. Willem Teelinck wrote in his Huysboeck (The Home Book; published posthumously in 1639):

alsdan so versamelde het gantsche huysgesin, jonch en out, en lasen $t^{\prime}$ samen een capittel vervolgens uyt de H. Schrift; alsoo bereyt zijnde door het lesen des Woorts, riepen sy eendrachtelyck met ghebogen knyen den naem des Heeren aen; daerna aen tafele [...], spraken sy $t^{\prime}$ samen van het gene een yder uyt het capittel bemerckt hadde [...]; na den eten songen sy $t^{\prime}$ samen eenen Psalm, dan keerde sich een ygelijck wederom tot syn werck. (Meeuse 1978)

[So gathered the whole family, the young and old alike, and they read together a chapter from the Holy Scripture; having been prepared by reading of the Word, they worshiped on their knees the name of the Lord; then, at the table [...] they discussed together what they noticed in this very chapter [...]; after the meal they all sang a psalm, and having done this, everybody returned to his work.] ${ }^{1}$

Another important aspect was the national ideology of Nederkinderen Israëls, the New Children of Israel, according to which the Dutch perceived themselves as the spiritual successors of the chosen Jewish nation (Ziemba 2000: 148-189, Schama 1987: 93-125). Numerous analogies were found in the Republic: overthrowing the Spanish rule was seen as the counterpart of the biblical Exodus, William the Silent being regarded as a new Moses. The enemies of the Republic were called Amalekites (and equally deserved their bad fate), the colonial expansion was compared to the rightful conquer of the promised Canaan, the preachers would compare the sinners to Philistines and Sodomites and make them responsible for the new Flood, obviously soon to happen. In the didactic and theological writings Dutch women were advised to look up to patriotic Esther, brave Judith or virtuous Susanna. Moreover, Calvinistic iconoclasm perfectly corresponded with the condemnable worship of golden calves and false deities. The narratives from the Old Testament served as a constant point of reference, political and confessional propaganda, and social models. The powerful national myth of Nederkinderen Israëls appealed not only to the reformed members of the society - due to the Calvinist catechization of education, it "introduced a common semantic field" for all citizens of the Republic (Frijhoff 2002: 51).

In my opinion, it may also be the reason for which the representations from the Old Testament slightly prevailed in the iconography of Dutch biblical tiles. Naturally, the Old Testament, owing to its bigger size, provided the artists (the engraver

${ }^{1}$ Translation mine - PO. 
and the tile painter that followed the prints) with more themes than the New one. For instance, Pieter Schut's Toneel ofte Vertooch der Bybelsche Historien contains 336 biblical engravings, out of which 192 (57\%) illustrate the Israelite part of the Bible and $144(43 \%)$ the Christian one. In the repertoire of so far registered biblical motifs used in Dutch tiles (the archive of Jan Pluis) this proportion diminishes to $54 \%$ and $46 \%$, though these figures refer only to the iconographical frequency of the motifs and not their actual occurrence on the walls, chimney-places and the output of the tile manufacturers (which demands further quantitative research).

Both production of the biblical tiles in the Republic and their presence in the Dutch interiors may be also interpreted in the wider social context, namely the 'biblicisation' of everyday life from the seventeenth century onwards, a phenomenon which, according to Antoni Ziemba (2000: 51-59), could be perceived as a "massive visual attack." This cultural process was bilateral and, on one hand, it concerned depicting biblical scenes in a typical Dutch setting, including landscape, nature, home life, costume, and custom. The tradition of inscribing the Biblical motifs into the local contexts was a part of the European Christian imaginarium (in the Low Countries already evident in the works of the late-medieval Flemish Primitives) but in the seventeenth-century Republic it started to flourish and blossom on an enormous scale. Abraham Bloemaert painted Tobias and the Angel with a huge dovecote (duiventil) in the foreground (ca. 1630, Centraal Museum, Utrecht), Pieter Jansz. Post placed the parting of Abraham and Lot in the Dutch rural scenery (ca. 1630, Frans Hals Museum, Haarlem), in Marcus Ormea's painting risen Christ (according to the Gospel of John, chapter 21) appears in front of his disciples on the beach of the North Sea (ca. 1630, Openbaar Centrum voor Maatschappelijk Welzijn, Bruges), Jan Steen's The Marriage Bed of Tobias and Sarah (ca. 1660, Museum Bredius, The Hague) is a perfect Dutch genre scene (Van den Berg et al. 2014: 68-123). Representing the biblical stories in the familiar, common, often even plebeian setting was greatly appreciated by the viewers and played a crucial role in the catechization programme, the fact well proven by the exhibition Het Oude Testament in de Schilderkunst van de Gouden Eeuw [The Old Testament in Painting of the Golden Age, Joods Historisch Museum, Amsterdam 1991] and the accompanying catalogue (Tümpel 1991). Because tiles followed prints (which were often based on the German works of Merian and the engravers from Antwerp), their iconography hardly reveals the specific, 'onlyDutch local setting' (and distinguishing it from the general Northern-European cultural context poses a great difficulty). Nativity scene in front of a 'typical' Dutch house from ca. 1710 (fig. 33) and Tobias and Sarah kneeling in a Dutch interior from ca. 1650 (fig. 32) may be seen as rare exceptions. The fact that the stencil makers and tile painters from Utrecht (fig. 19, 20,21) left out the camels from the print (fig. 18) and added an ox in the stable, had probably more to do with the 
technical issues than with the intention to make the scene look more familiar. However, sometimes the Dutch engravers slightly altered Merian's prints having the Dutch viewers in mind - e.g. Pieter Schut changed one of Merian's scenes so it would better correspond with the Statenvertaling (Pluis 1994: 254, 579).

On the other hand, the 'biblicisation' of the everyday life in the Republic would equally mean including the biblical motifs in the widely understood personal, material sphere of the household. Not only the biblical narratives were 'made look Dutch,' but also the Dutch interiors constantly referred to the Bible as a source of decoration and it did not only concern the paintings hanging on the walls. Furniture, tapestries, stained glasses, toilet utensils, cutlery, jugs, and dishes started to be frequently embellished with the scenes from the Old Testament. The purpose of such representations was often didactic - e.g. Joseph rejecting the advances of Potiphar's wife painted on a linen cupboard emphasised the virtues of the marriage bed (Ziemba 2000: 54-55). Although Calvinist theologians and ministers Verbi Dei did oppose biblical representations in churches and the wave of Reformation in the Low Countries was followed by the outburst of beeldenstormen, home furnishings and utensils had a completely different function - they were not the objects of cult and worship but the carriers of moral messages. Many such objects were shown at two exhibitions in the Museum Catharijnenconvent in Utrecht: De Bijbel in huis. Bijbelse verhalen op huisraad in de zeventiende en achttiende eeuw [The Bible at home. Biblical narrations on home furnishings in the seventeenth and eighteenth century, 1991] and Thuis in de Bijbel. Oude meesters, grote verhalen [At home in the Bible. Old masters, big narrations, 2014], followed by the enlightening catalogues (Defoer et al. 1991; Van den Berg et al. 2014). Biblical tiles undoubtedly belonged to exactly the same category and provided the family members with similar pious lessons. It must be noted that both the furnishings and tiles were probably not perceived by the Dutch viewers as Biblia pauperum, teaching the simple illiterate folk about the Scripture from scratch (most of them could actually read), but as a reminder and revision of the knowledge they had already possessed.

Antoni Ziemba in his most instructive book Nowe Dzieci Izraela. Stary Testament w kulturze holenderskiej XVII wieku [The New Children of Israel. Old Testament in the Dutch Culture of the Seventeenth Century, 2000 - unfortunately published in Polish only], stressed the fact that the nationwide 'biblicisation' of the Republic's interiors lost its impact ca. 1660-1670 when the most affluent elites gave up the ostentatiously Protestant figurative embellishment for ornaments and subtler decorations. Though, the biblical decorative trend, visible especially in furniture, remained alive in folk culture still up to the nineteenth century. It was much favoured by the Mennonites from the area of Zaanstreek, and later on it spread in the Republic's countryside (Ziemba 2000: 56-57). The dynamics of this 
process correspond clearly with the occurrence of Dutch biblical tiles on the walls. They actually hardly made their way to the wealthiest interiors, but being the most expensive products in the offer of tile works, could not be found in the kitchens, corridors, cellars, and warehouses either. When the production of the bijbeltegels reaches its peak in the eighteenth century, they started to cover the walls and chimney-places (smuigers) of the Mennonite houses in Zaanstreek (fig. 28, 30), then reached the lower-middle-class interiors and, finally, the farmhouses (fig. 27).

Biblical tiles have been discussed in a great detail by Jan Pluis in his impressive book Bijbeltegels. Bijbelse voorstellingen op Nederlandse wandtegels van de 17e tot de 20e eeuw. Bibelfliesen. Biblische Darstellungen auf niederländischen Wandfliesen vom 17. bis zum 20. Jahrhundert [Biblical tiles. Biblical representations on Dutch tiles from the seventeenth to the twentieth century, 1994]. Bulky as it is, it presents and describes only 1895 objects (the researcher's private archive is six times vaster). Other important studies on the subject include Mit Bilderfliesen durch die Bibel by Kurt Perrey, Ein Fliesenschatz in Klosterzellen. Bibelfliesen im Kloster Lüne by Marlis Anders, and texts published by Wilhelm Joliet at the website Die Geschichte der Fliese. ${ }^{2}$ Moreover, the German Protestant community from Eastern Friesland, Evangelisch-lutherischer Kirchenkreises Norden, in 2008 succeeded in publishing Fliesenbibel, the Tile Bible, in which the text of the Old and New Testament has been accompanied by the appropriate reproductions of 600 Dutch tiles, not to mention numerous exhibitions and catalogues edited under its auspices.

It is almost impossible to list all interesting museum collections and interiors decorated with Dutch biblical tiles but (to name just few), German castles and palaces of Amalienburg, Oranienbaum, Eutin, and Bothmer; old estate Sielhof in Neuharlingersiel (fig. 31); cloister Lüne; the béguinage of Bruges; the church of Santa Maria and Hospital de San Juan de Dios in Cádiz; or the palace Casa do Paço in Portugese Figueira da Foz are definitely worth a visit. In Poland the best examples are to be found on the walls of the palaces in Wilanów (the Faience Cabinet; Oczko and Pluis 2013: 81-89); the Beyersdorf Room in Wrocław (Szmida-Półbratek 2010) and Lower-Silesian Pakoszów (German Wernersdorf); in the lavabo of the Malbork castle; moreover, in the collections of the National Museum in Gdańsk and the Archaeological and Historical Museum in Elbląg (the tiles from the former Mennonite houses from Żuławy Wiślane). Here an intriguing question pops up: did the Mennonites from Żuławy follow the taste for biblical tiles, typical for their Netherlandish ancestors? As we know, their Vorlaubenhäuser were richly decorated with Dutch tiles - unfortunately only very few such interiors have been (partially) preserved and future research has to be merely based on tracing the archival sources. In the past, there used to be many more

${ }^{2}$ Die Geschichte der Fliese. 1 Feb. 2015. <http://www.geschichte-der-fliese.de>. 
interiors decorated with biblical tiles all over the Polish-Lithuanian Commonwealth. The description of the Radziwiłłs palace in Ołyka from 1772 mentioned the walls on which "the faiences with stories from the Scripture with blue varnish per misteriam painted" were displayed (Przywoźna-Leśniak 2013).

Today in the Netherlands, Dutch tile almost reached a status of a national symbol, being a constant point of reference and a link between the present and the past. It is just enough to name its big comeback in the twentieth century (Pluis 2008), the phenomenon also exemplified by the recently opened tunnel for the cyclists and pedestrians in Amsterdam (fiets- en voetgangerstunnel) decorated with handpainted tiles (designed by Irma Boom, manufactured by Royal Tichelaar in Makkum, 2014, fig. 34) or the heating plant (stadsverwarming) in Enschede (designed by Hugo Kaagman, 2009). Tile heritage is also used for commercial purposes, like gift wraps, chocolate boxes, and numerous kitschy souvenirs (Van der Wees 2012). In this context the KLM advertising campaign "Tile Yourself" from 2011 is especially worth mentioning: the users of the social media were invited by the company to create their own tile-portraits, some of which actually ended on the bodies of the real KLM aircrafts. Moreover, tiles, as the iconic representations of the Dutch national identity, are constantly reinterpreted by modern artists and even serve as a medium for various social campaigns. An interesting example may be the project of Ien van Laanen, an artist from Amsterdam, who designed a series of tiles presenting various aspects of the contemporary Dutch life, at the same time providing us with the ironic comment upon the power of the stereotypes. Her tiles were used as illustrations for the series of articles published by Wilma de Rek and Bert Wagendorp, first in de Volkskrant and then in a book form as Encyclopedie der Nederlanden [The Encyclopaedia of the Netherlands, 2011]. In Ien van Laanen's works traditional themes such as landscapes, shepherds, cupids, and playful kids gave way to pictorial representations of the proverbial Dutch tolerance, same-sex marriage, women lib, not to mention other modern Dutch associations as cheese slicers, football supporters, traffic jams, rijsttafelen, Keukenhof, or de Stijl.

Though the Bible is practically non-existent in the Dutch imaginarium of today and the modern viewers could hardly tell the difference between the iconographic representations of the flight to Egypt and the expulsion of Ishmael and Hagar, the tile history in the Netherlands is by no means over.

The author wishes to expresses sincere thanks to his friend and the greatest tile-teacher Jan Pluis for his kindest advice, constant guidance, and patience. 


\section{Bibliography}

Andres, Marlis. 2013. Ein Fliesenschatz in Klosterzellen: Bibelfliesen im Kloster Lüne. Lüne: author's own edition.

Berg, Anne Jaap van den et al., eds. 2014. Thuis in de Bijbel. Zwolle: WBOOKS.

Defoer, H.L.M. et al., eds. 1991. De bijbel in huis: Bijbelse verhalen op huisraad in de zeventiende en achttiende eeuw. Utrecht-Zwolle: Waanders.

Fliesenbibel. 2012 . $2^{\text {nd }}$ ed. Weener: H. Risius.

Frijhoff, Willem. 2002. Embodied Belief: Ten Essays on Religious Culture in the Dutch History. Hilversum: Uitgeverij Verloren.

Gruber, Alain et al., eds. 1994. The History of Decorative Arts: The Renaissance and Mannerism in Europe. New York, London, Paris: Abbeville Press.

Huijg, Adriaan, O.S.B, ed. 1978. De Bijbel op tegels. Boxtel: Katholieke Bijbelstichting.

Jonge, Caroline Henriëtte de. 1971. Nederlandse tegels. Amsterdam: J. H. De Bussy.

Kamermans, Johan, ed. 2013. Verglaasde Charme: De Schoonheid van de Nederlandse Tegel. Glazed Charm: The Beauty of Dutch tiles. Zwolle: SPA-Uitgevers.

Meeuse, C.J. 1978. "Huisgodsdienst.' Digibron. Kenniscentrum gereformeerde gezindte. 1 Feb. 2015. <http:/ / www.digibron.nl/search/detail/a063d3d000c772842e354e3cd2e2e115/ huisgodsdienst $>$.

Oczko, Piotr, Jan Pluis. 2013. Gabinet Farfurowy w patacu w Wilanowie: Studium historycznoikonograficzne. Warszawa: Muzeum Pałacu Króla Jana III w Wilanowie.

Oczko, Piotr. 2013. Miotta i krzyż: Kultura sprzątania w dawnej Holandii, albo historia pewnej obsesji. Kraków: Collegium Columbinum.

Perrey, Kurt. 2005. Mit Bilderfliesen durch die Bibel. Weener: H. Risius.

Pluis, Jan. 1969. Tegels met bijbelse voorstellingen. Zutphen: Tesink. 1994. Bijbeltegels. Bijbelse voorstellingen op Nederlandse wandtegels van de 17e tot 20e eeuw. Bibelfliesen. Biblische Darstellungen auf niederländischen Wandfliesen vom 17. bis zum 20. Jahrhundert. Münster: Ardey-Verlag. . 2008. Nederlandse Tegels 1900-2000. Leiden: Primavera Pers.

2013. De Nederlandse Tegel, decors en benamingen 1570-1930/The Dutch Tile: Designs and Names 1570-1930 [met medewerking van Daniël Hanekuijk, Piet Bolwerk en Jan van Loo]. $3^{\text {rd }}$ ed. Leiden: Primavera Pers.

Poortman, Wilco C. 1983-1986. Bijbel en prent. Vols.1-2. 's-Gravenhage: Boekencentrum.

Przywoźna-Leśniak, Katarzyna. 2012. "Między Wersalem a Peterhofem. Holenderskie płytki ścienne w wystroju rezydencji arystokratycznych w XVII i XVIII wieku." Barok. Historia - Literatura - Sztuka 38: 155-163.

2013. “Farfurki błękitnym pokostem per misteria malowane. Holenderskie płytki ścienne w wystroju rezydencji magnackich na wschodnich terenach dawnej Rzeczypospolitej (województwo ruskie, wołyńskie i wileńskie)." Stan badań nad wielokulturowym dziedzictwem dawnej Rzeczypospolitej. Eds W. Walczak, K. Łopatecki. Vol. IV. Białystok: IBNDKE. 423-431.

Rek, Wilma de, Bert Wagendorp, and Ien van Laanen. 2011. Encyclopedie der Nederlanden. Amsterdam-Antwerpen: Atlas.

Schama, Simon. 1987. The Embarrassment of Riches: An Interpretation of Dutch Culture in the Golden Age. London: Fontana Press.

Sprangers, Peter. 2013. Utrechtse tegels: 1600-1900. Utrecht: Stili Novi. 
Stoffels, Francine. 2014. “Boumeester herleeft in Amsterdam: Een nieuwe betegeling naar een oud tableau." Tegel 42: 46-51.

Szmida-Półbratek, Magdalena. 2010. Świat zaklęty w btękicie. Pokój Beyersdorfów w Pałacu Królewskim we Wroctawiu. Die in Azur verzauberte Welt. Beyersdorf-Zimmer im Köningschloss in Breslau. Wrocław: Muzeum Miejskie Wrocławia.

Tümpel, Christian, ed. 1991. Het Oude Testament in de Schilderkunst van de Gouden Eeuw. Zwolle, Amsterdam, Jeruzalem: Waanders.

Wees, Trudy van der. 2012. Door Delfts blauwe ogen: In de ban van een nationaal icoon. Soest: Boekscout.nl.

Ziemba, Antoni. 2000. Nowe dzieci Izraela: Stary Testament w kulturze holenderskiej XVII wieku. Warszawa: Neriton.

\section{List of illustrations}

1. Tiled floor in the abbey of Herkenrode, 1532. Photo: Jan Pluis.

2. Landscape with a castle and a well, Cornelis Boumeester, Rotterdam, ca. 1710-1730. Photo: Jan Pluis.

3. Pastoral scene, workshop of Geradus van Oort, Utrecht, ca. 1680. Photo: Piotr Oczko.

4. Rhinoceros, based on Albrecht Dürer's engraving from 1515, Utrecht, workshop of Gebr. Ravesteyn, ca. 1850. Photo Jan Pluis.

5. Boy playing whip-top, Rotterdam, ca. 1635-1650. Photo: Jan Pluis.

6. Cupid sitting on a skull and holding a flower (a symbol of transition), ca. 1640. Photo: Jan Pluis.

7. Triton playing with a mermaid, Harlingen, ca. 1660. Photo: Jan Pluis.

8. Cargo ship (fluit), Harlingen, ca. 1670. Photo: Nederlands Tegelmuseum.

9. Fox preaching on the Passion of Christ, Rotterdam (?), ca. 1630. Photo: Jan Holtkamp.

10. Woman lifting her skirt up, ca. 1640. Photo: Jan Pluis.

11. 6 biblical tiles, Amsterdam, ca. 1740. Photo: Jan Pluis.

12. 6 biblical tiles painted by Adam Sijbel and based on the engravings by Pieter Schut, Makkum, ca. 1790. Photo: Jan Pluis.

13. The conversion of Saul, tile picture from Vleeshuis in Antwerp, 1547. Photo: Jan Pluis.

14. Tile picture representing the Immaculate Heart of Mary, Tjallingii workshop, Harlingen, ca. 1890-1900. Photo: Peter Mooij.

15. Tile picture representing the representing the Sacred Heart of Jesus, Tjallingii workshop, Harlingen, ca. 1890-1900. Photo: Peter Mooij.

16. Copper engraving plate by Mattheüs Merian with Adoration of the Magi for his Icones Biblicae, ca. 1625-1627. Photo: Jan Pluis.

17. Adoration of the Magi, print form Mattheüs Merian's Icones Biblicae, ca. 1625-1627. Photo: Jan Pluis.

18. Adoration of the Magi, print form Nicolaes Visscher's Historiae sacrae..., 1650. Photo: Jan Pluis.

19. Pricked stencil representing Adoration of the Magi, workshop Agter 't Weystraat, Utrecht, ca. 1750-1760. Gemeente Museum Het Hannemahuis, Harlingen. Photo: Het Hannemahuis. 
20. Adoration of the Magi, Utrecht, ca. 1760-1770. Photo: Leen den Toom.

21. Adoration of the Magi, Utrecht, ca. 1790. Photo: Jan Pluis.

22. Susanna and the Elders, Jan Eelkes, Harlingen, ca. 1780. Photo: Jan Pluis.

23. Virgin Mary (Onze Lieve Vrouw), Ludolf Bakhuizen's workshop, Rotterdam, ca. 1760. Nederlands Tegelmuseum, Otterlo. Photo: NederlandsTegelmuseum.

24. Samson drinking water from the ass's jaw, Amsterdam, ca. 1650. Photo: Jan Pluis.

25. Menshikov Palace, St. Petersburg, tiles from Utrecht and Harlingen, ca. 1672-1729. Photo: Frans Dronkers.

26. Interior of a farm house in St. Kruis in West Flanders (ca. 1784), tiles made in the workshop Het Wapen van Dantzich in Rotterdam, ca. 1785. Photo: Jan Pluis.

27. Interior of a farm house with biblical tile pictures in Cillaarshoek in South Holland (tiles made in Rotterdam, ca. 1780). Photo: Jan Pluis.

28. Smuiger decorated with biblical tiles, Zaanse Schans (Op de Glop), Amsterdam, ca. 1790. Photo: Jaap de Koning.

29. Little Philip Doddridge admiring his mother's chimney-place, illustration from Dutch Tiles: Being Narratives of Holy Scripture, London 1842.

30. Biblical tiles, detail of fig. 28. Photo: Jaap de Koning.

31. Biblical tiles in the inn Sielhof, Neuharlingersiel, Amsterdam, De Twee Romeinen workshop, ca. 1750. Photo: Achim Röder.

32. Tobias and Sarah kneeling in a Dutch interior, Amsterdam, ca. 1650. Photo: Jan Pluis.

33. Nativity scene in front of a 'typical' Dutch house, Harlingen, ca. 1710. Photo: Jan Pluis.

34. Tunnel for bikers and pedestrians under the Central Station in Amsterdam, designed by Irma Boom, manufactured by Royal Tichelaar in Makkum, 2014. Photo: Tom Swaab.

35. 48 biblical tiles from a series consisting of ca. 137 motifs, Utrecht, workshops of Achter 't Weystraat and Gebr. Ravesteyn, ca. 1860-1870. Photo: Piotr Oczko. 

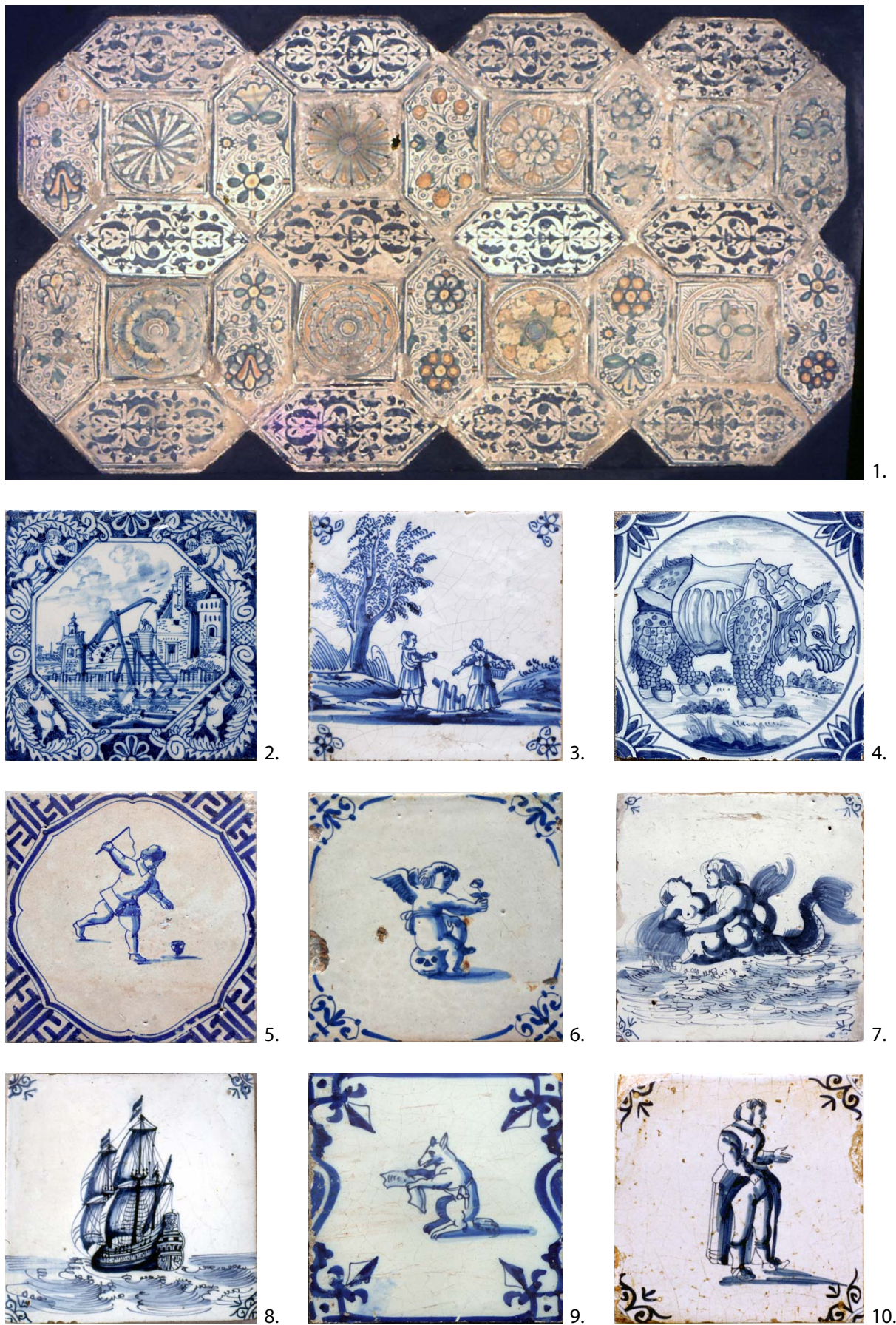

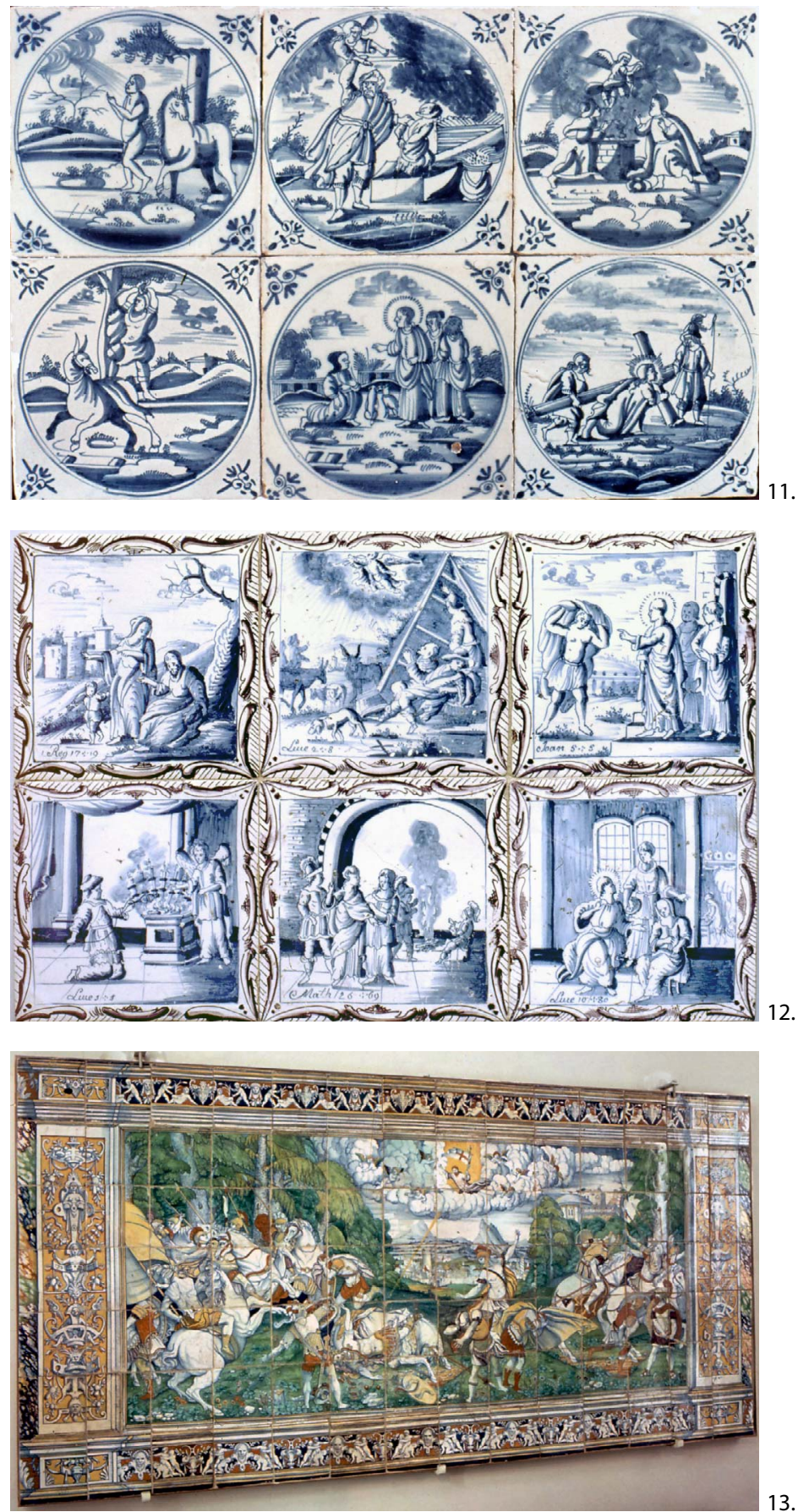

13. 

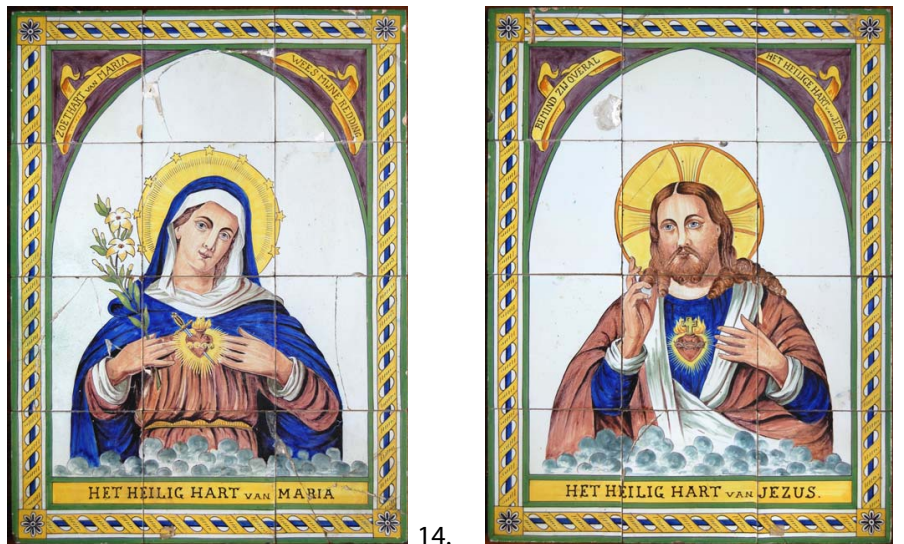

15.

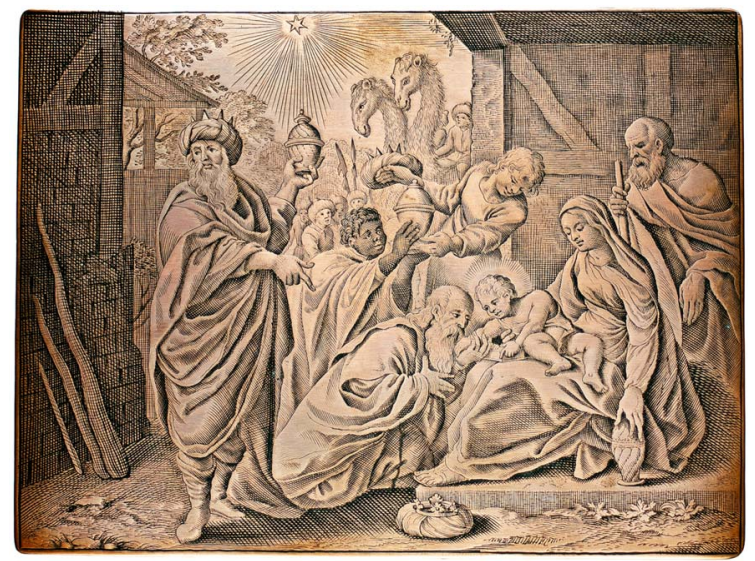

16.

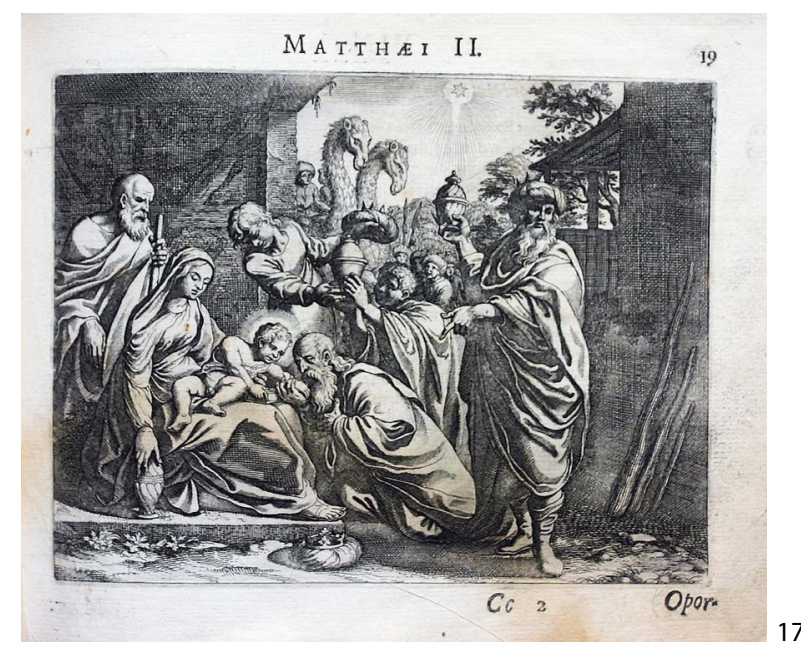




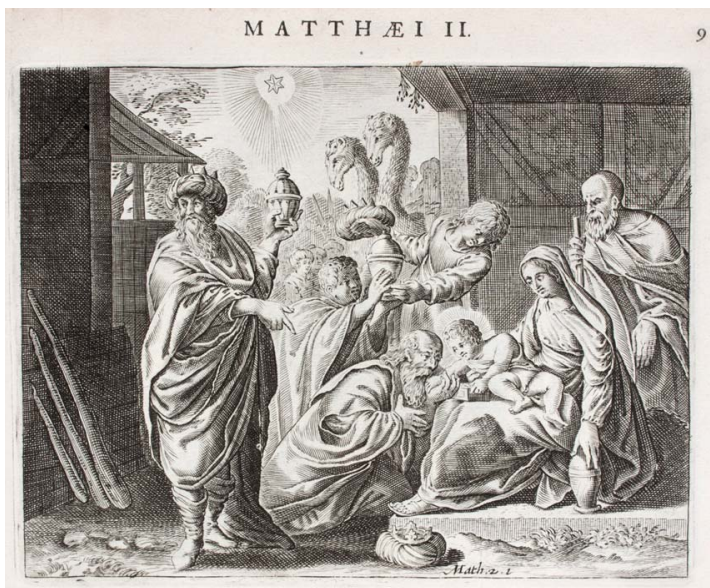

PRIMITIÆ GENTIUM.
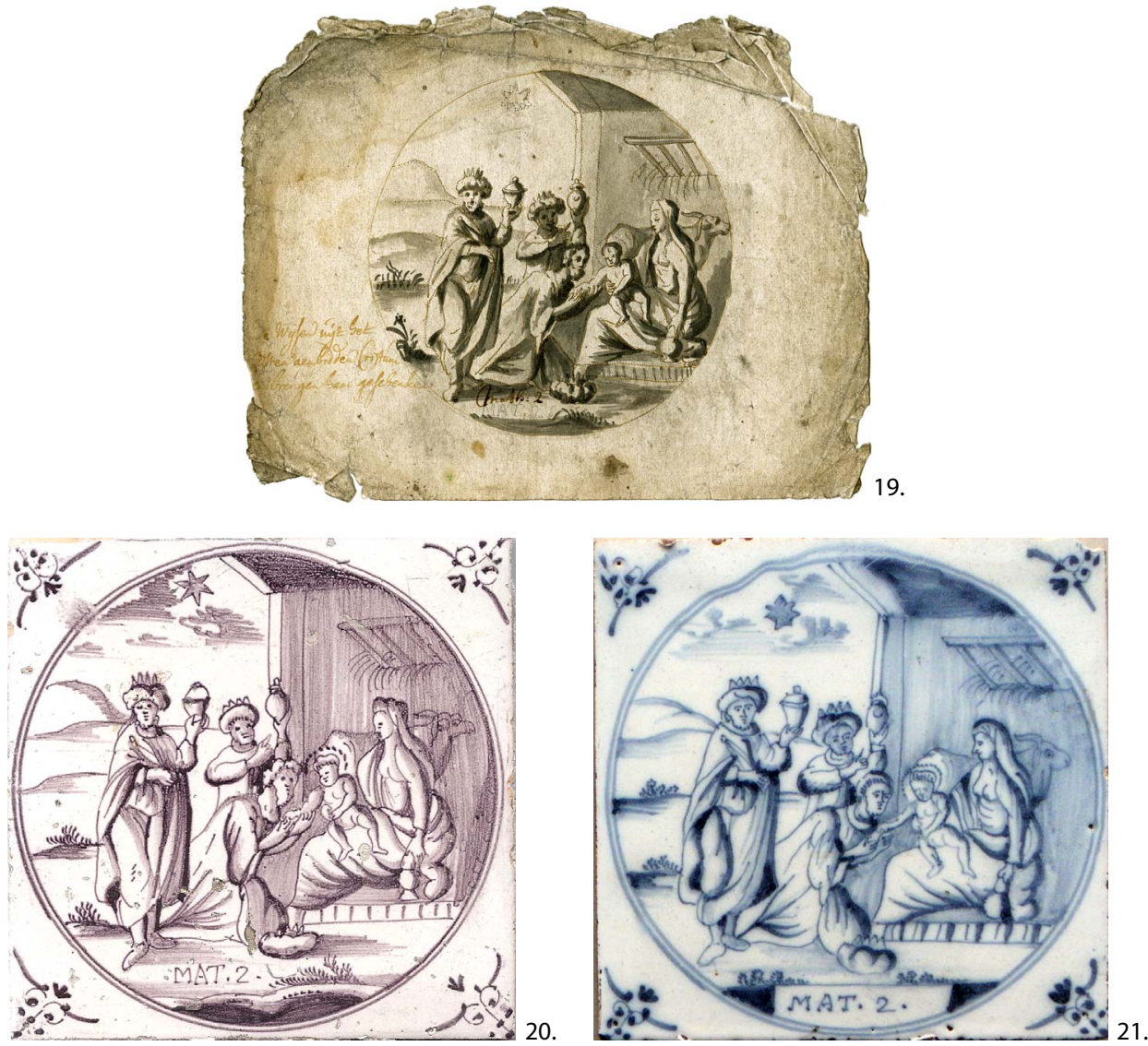

10(2) 2015 werkwinkel 

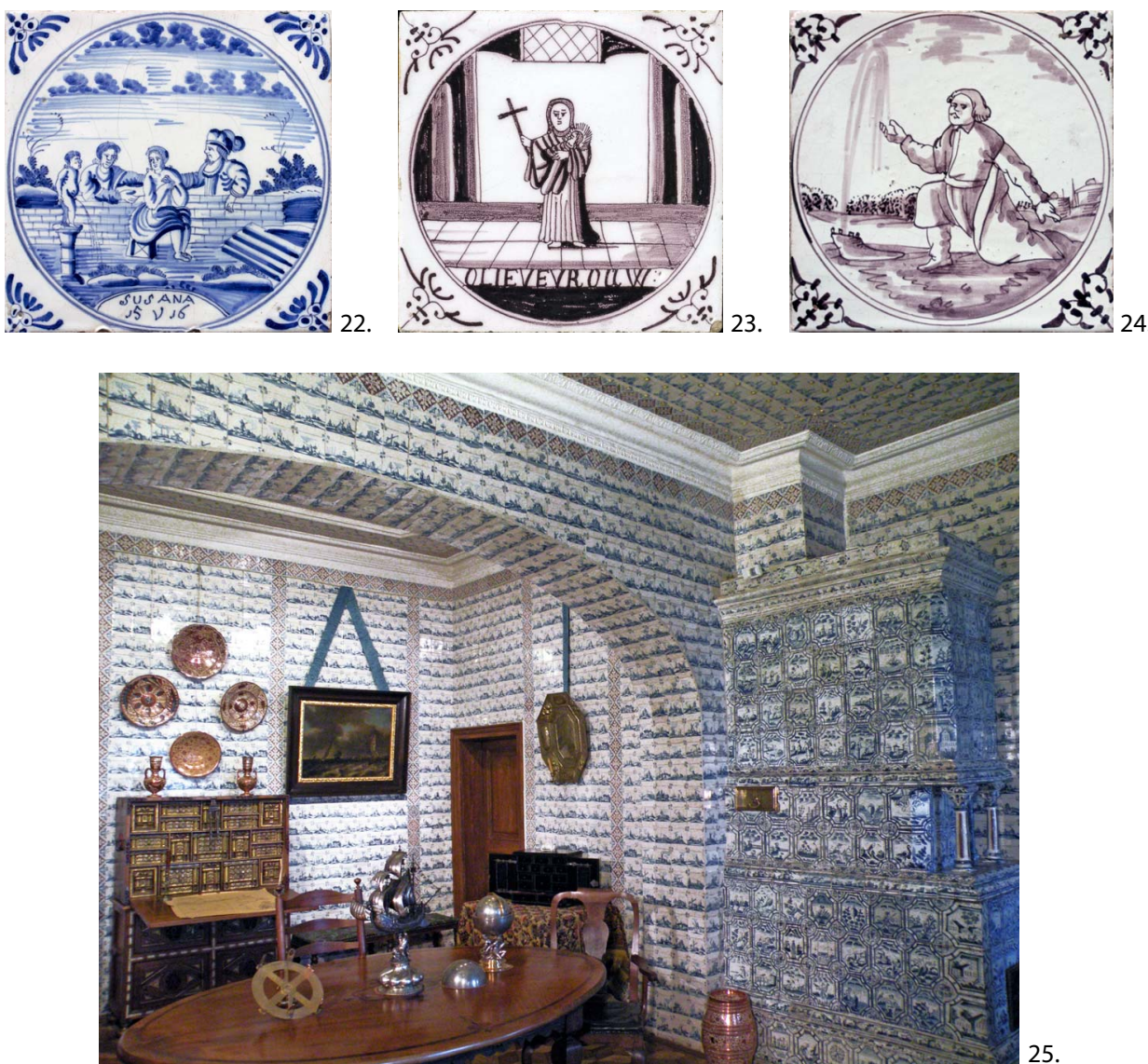

25.

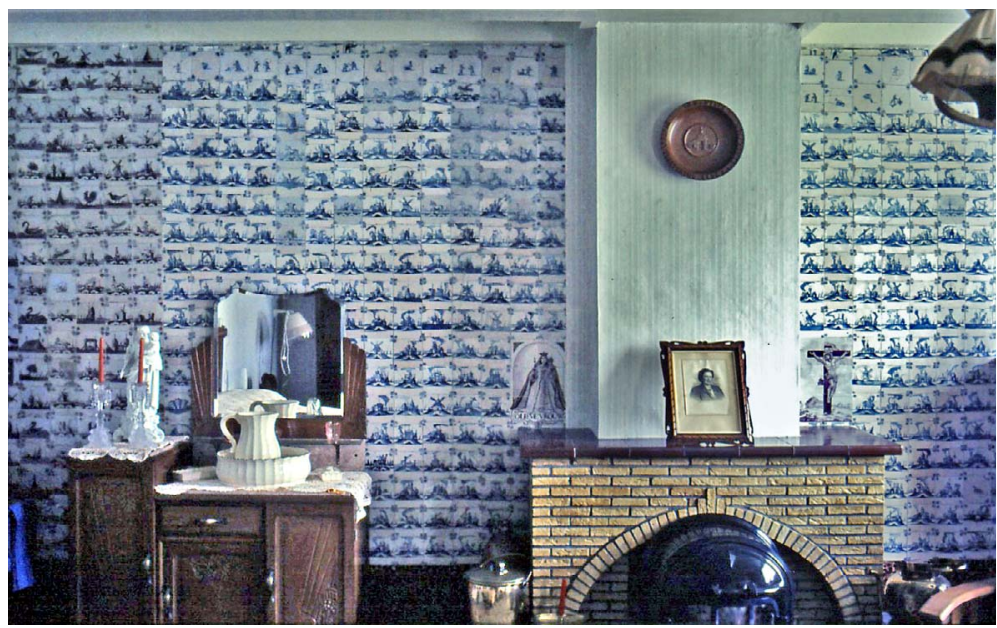



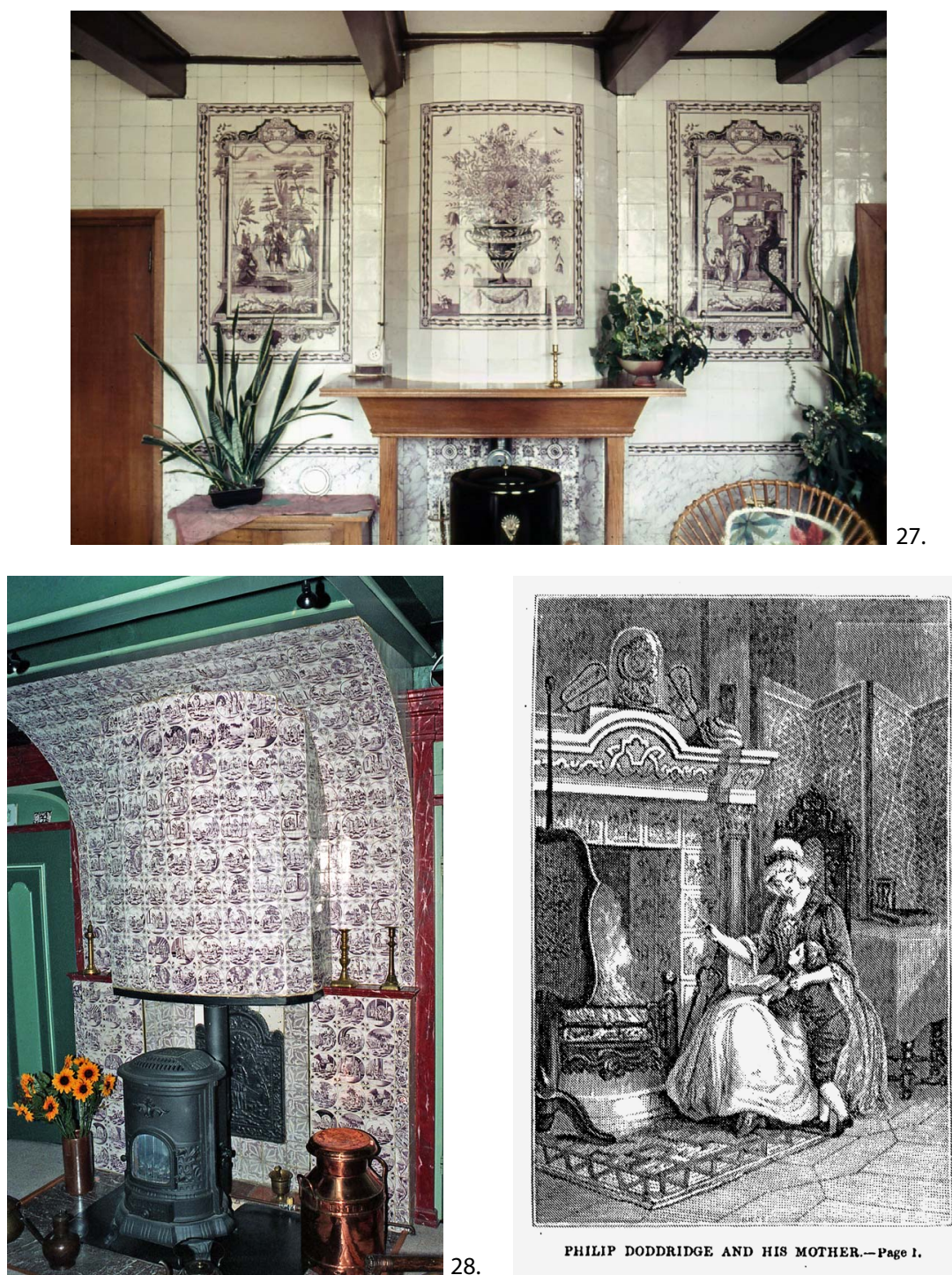

28.

PHILIP DODDRIDGE AND HIS MOTHER-PORO 1 .

29.

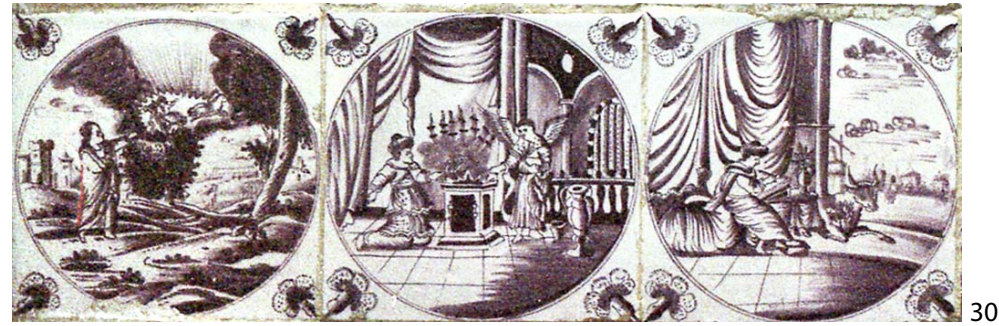

10(2) 2015 werkwinkel 

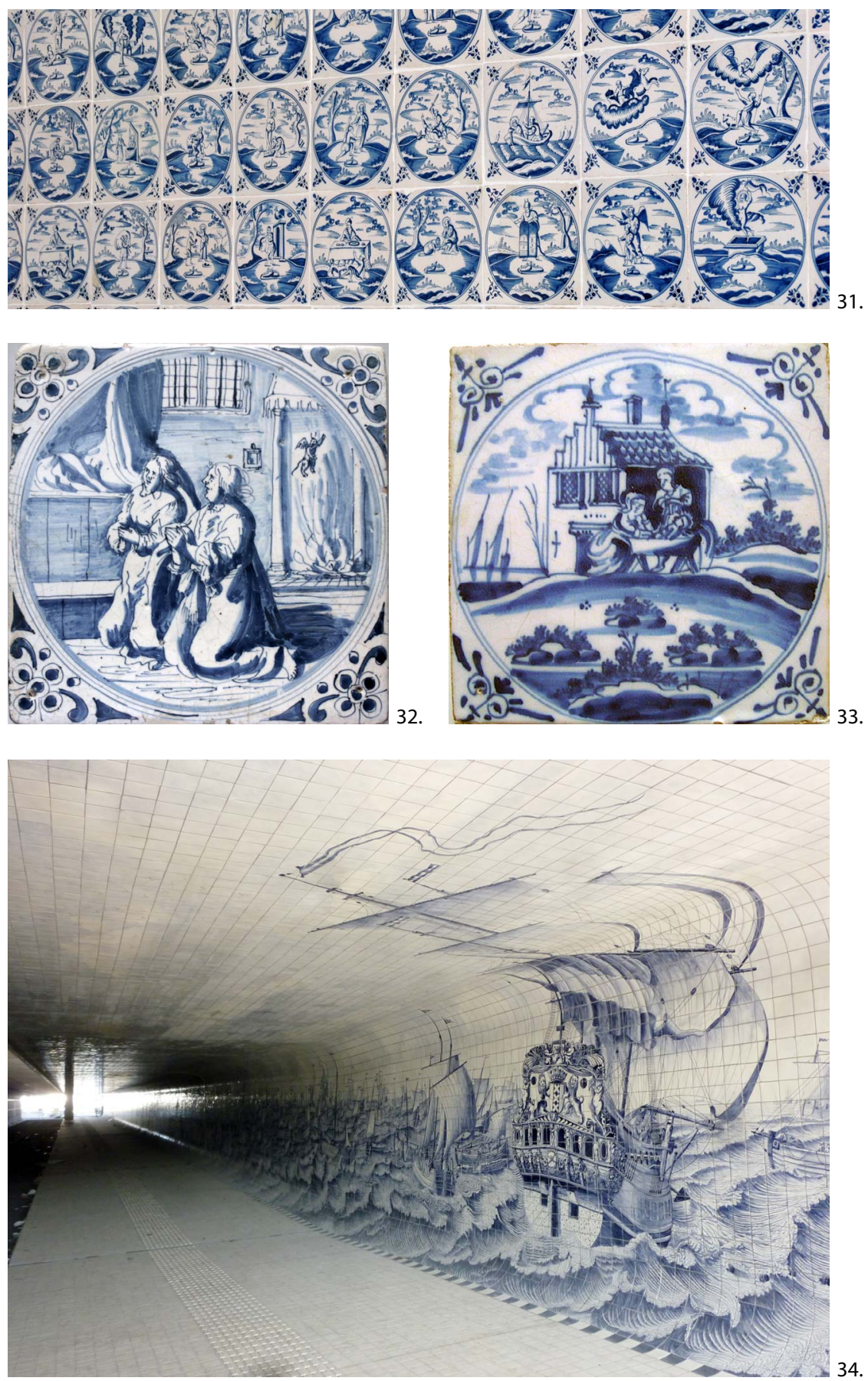

34. 
Piotr Oczko

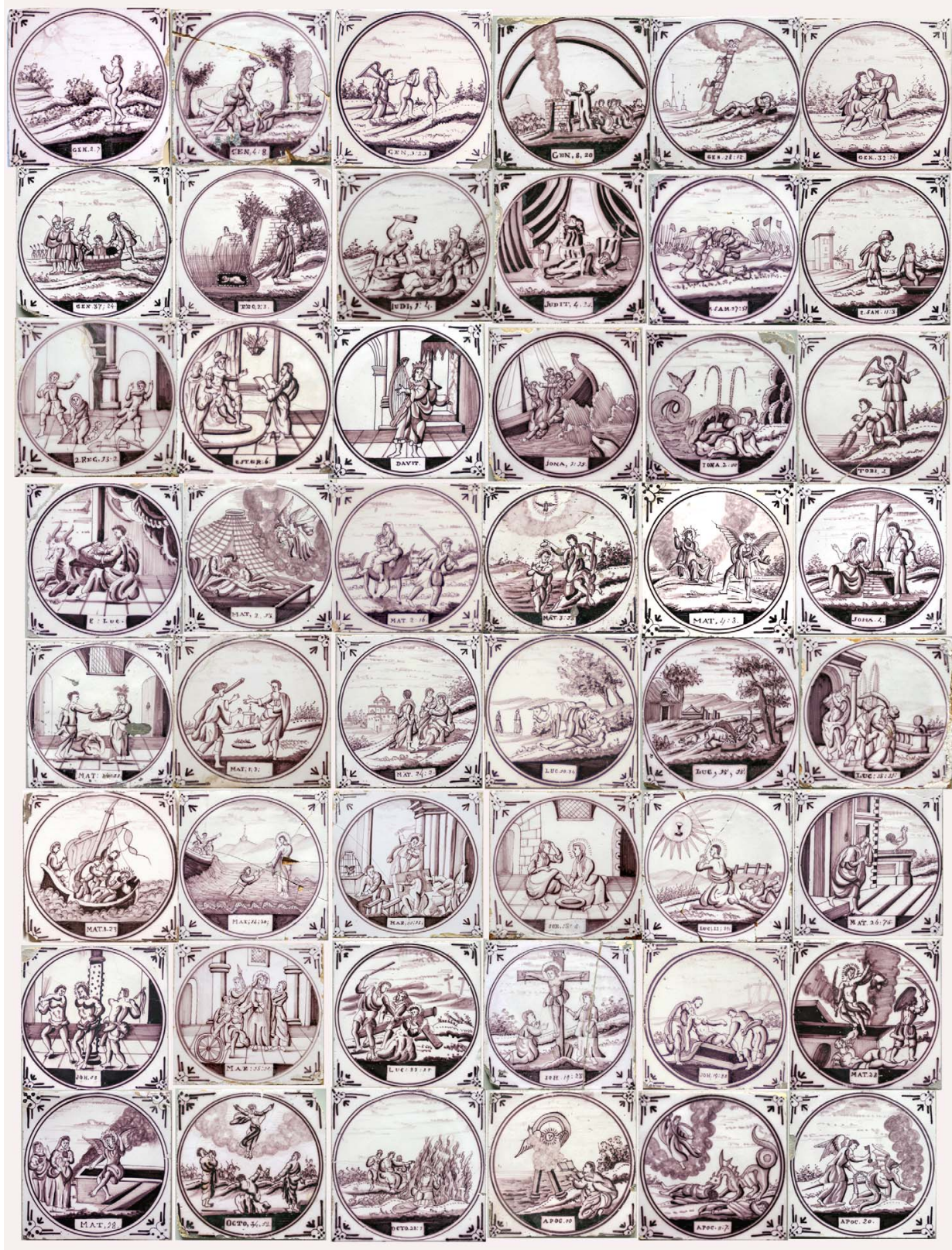

